\title{
SEPARATING OF APRICOT PITS KERNEL USING PNEUMATIC SYSTEM
}

\author{
Tayle, S.A. ${ }^{(1)}$ A.K. Zaalouk ${ }^{(2)}$ A.E. Abdelhameed ${ }^{(3)}$ E.R. Shousha ${ }^{(4)}$
}

\section{ABSTRACT}

Separation of apricot kernel from shells is important processes to use the kernel and shells. In this study, some physical properties were studied for apricot kernel and shells. pneumatic separator was used and separation module performance was investigated as a function of change in air stream velocity of $9,10,11$ and $12 \mathrm{~m} / \mathrm{s}$, feeding rate of $30,60,90$ and 120 $\mathrm{kg} / \mathrm{h}$, mixture moisture contents of 5.76, 14.46 and $21.67 \% \mathrm{w} . \mathrm{b}$. and screen slope of 25 and $35^{\circ}$. The results revealed that, optimum operations conditions were obtained at $11 \mathrm{~m} / \mathrm{s}$ air velocity, feeding rate of $120 \mathrm{~kg} / \mathrm{h}$, mixture moisture content of $14.46 \%$ and screen slope of $25^{\circ}$, the separation effectiveness of $96.18 \%$, kernel cleanliness of $93.83 \%$, kernel losses of $0.69 \%$, kernel productivity of $40 \mathrm{~kg} / \mathrm{h}$, specific energy of 4.22 $\mathrm{kW} . \mathrm{h} / \mathrm{Mg}$ and cost of 96 L.E./Mg.

\section{INTRODUCTION}

pricot (Prunus armeniaca L.) is one of the major horticultural
crops in Egypt due to its export importance and several uses in
many food industries. The annual world production for apricot exceeds 3.9 million Mg. Turkey is the biggest apricot producer country in the world with about $676138 \mathrm{Mg} /$ year. Egypt is the eleventh producer country in the world with about $96643 \mathrm{Mg} /$ year (FAO, 2011). Cultivation area in Egypt is about 14874 fed., with production is about $6.5 \mathrm{Mg} / \mathrm{fed}$. Approximately $54 \%$ of the production comes from Noubaria region (Agric. Statistics Economic Affairs Sector, 2011). The apricot fruits comprising of $6-11 \%$ of the pits constitute about $22-38 \%$ of kernels (Shah, 1985). Pits of apricot are used in the production of active carbon. Important applications of activated carbons are related to their use in

(1) Prof. Emt. of Agric. Eng., Fac. of Agric. Eng., Al-Azhar Uni.

(2) Prof. and head of Agric. Mach. and power Eng. Dept., Fac. of Agric. Eng., AlAzhar Uni.

(3) Assoc. prof. of Agric. Eng., Fac. of Agric. Eng., Al-Azhar Uni.

(4) Demonstrator, Fac. of Agric. Eng., Al-Azhar Uni. 
water and industrial wastewater treatment for removal of flavor, color, odor and other undesirable organic impurities (Dorbrowksi, 2001). Apricot pits are also separated into shells and kernels in the regional conglomerates which have washing, sorting, breaking and separating units. The shells are generally used as fuel (Gezer et al., 2002). Crushed shells use to instead of anthracite coal in filters for water treatment (Aksogan et al., 2003). Apricot kernel contains 17.38\% protein, $48.70 \%$ crude oil, in addition to some elements such as sodium, potassium, calcium, phosphor, iron and zinc (Ozcan, 2000). Kernel is used in production of Benz aldehyde; cosmetics, aroma perfume, and food after remove glycoside amygdaline (Vursavus and Faruk, 2004). Pneumatic separators according to: the direction of air steam in separation duct, which may be divided into (horizontal, inclined and vertical air stream action); the manner of air stream in separation duct (suction or under pressure); circulation manner of air stream (closed or open) and according to number of ducts (one, two or multiple) (Foronaf and Baflofacke, 1959). Ismail et al. (1994) studied the effect of vertical airstream velocity, total impurities and specific feed rates on the cleaning efficiency of wheat grain at different moisture contents of mixture. They found that the highest values of cleaning efficiency with minimal losses were in the range of $93.45-99.46 \%$ at total impurities of $10 \%$, air velocity of $6-8 \mathrm{~m} / \mathrm{s}$ and moisture content of $15 \%$.

The main objectives of the present study are design, manufacture and evaluate the performance of a pneumatic apricot pits kernel separator.

\section{Apricot pits:}

\section{MATERIALS AND METHODS}

Experiments were carried out on local apricot pits, Al-amar species was used (Fig.1, a). Pits were cleaned to remove all foreign materials. Samples were broken by apricot pits cracker (Tayel et al, 2011) (Fig.1, b).

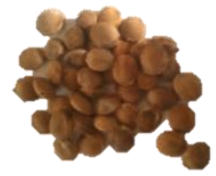

(a)

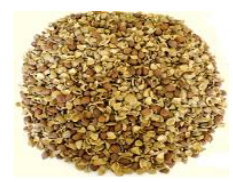

(b)

Fig. (1): (a) Apricot pits of Alamar, (b) kernel and shells mixture. 


\section{Separation unit:}

The separation unit was made from local materials. It was manufactured installed and tested at workshop of Faculty of Agricultural Engineering, AL-Azhar University. Figs. (2), (3) show an elevation and side view of separation unit, and assembling of separation unit respectively.

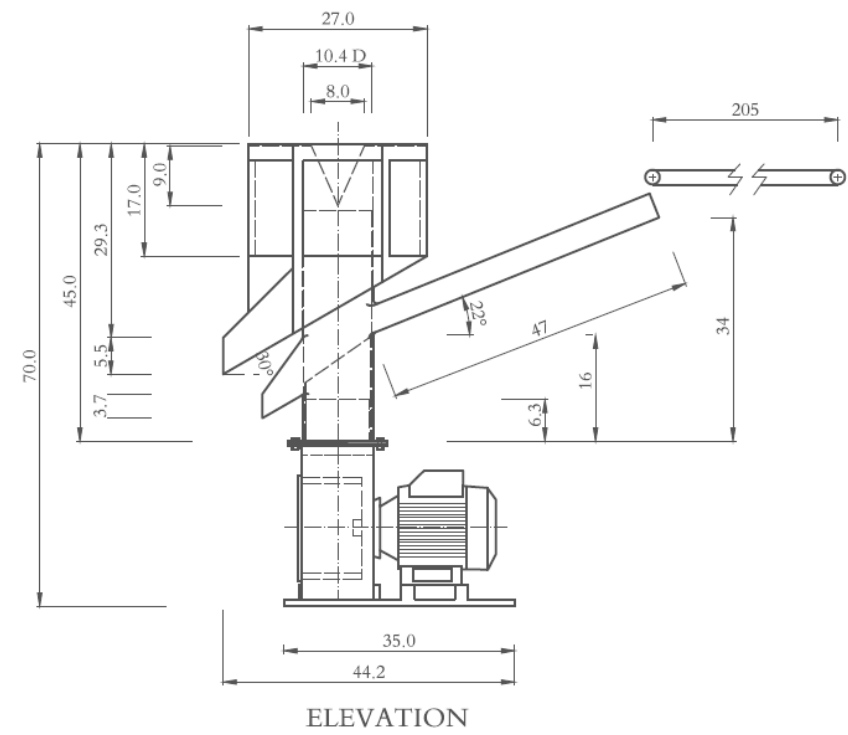

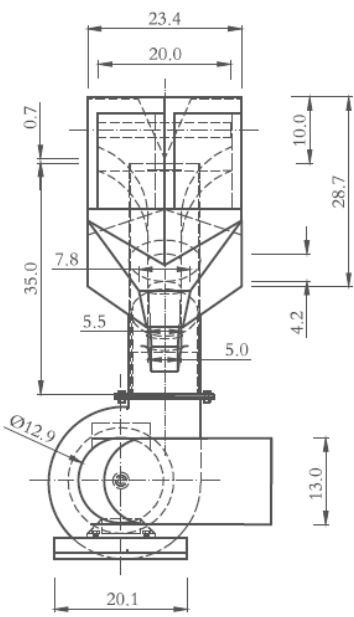

SIDE VIEW

(Dimensions in $\mathrm{cm}$. )

Fig. (2): Elevation and side view of separation unit.

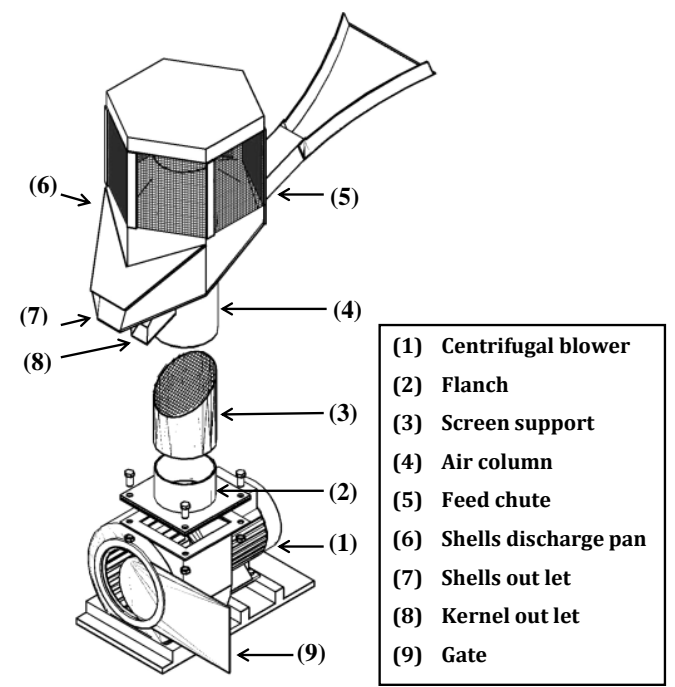

Fig. (3): Assembling of separation unit. 
The separation unit consists of Centrifugal blower (with outlet dimensions of 10x10 cm), used to push the air throw the air column. The power source is an electric motor of $0.37 \mathrm{~kW}$, single phase and rotation speed of $2850 \mathrm{rpm}$. Air flow is controlled by gate in blower inlet, a Flange that was fixed directly in the blower and designed to join the blower with the air column across the screen support, it is galvanized iron cylinder with $9.8 \mathrm{~cm}$ internal diameter and $16 \mathrm{~cm}$ high, upper face of this support on ellipse shape to easing kernel out of, wire screen used has openings of $4 \mathrm{~mm}^{2}$, air column (it is cylindrical shape with $10.4 \mathrm{~cm}$ internal diameter, $3 \mathrm{~mm}$ thick and $35 \mathrm{~cm}$ high). It made of UPVC material, air column has two openings; one of them to entry the mixture in middle column with dimensions $5 \times 4 \mathrm{~cm}$ and the other opening to exit the kernel at $7.8 \mathrm{~cm}$ horizontal distance from column base; with dimensions of $6 \times 8 \mathrm{~cm}$. Feed shut, it used to feeding mixture from hopper to air column. It made of fiberglass sheet with $2 \mathrm{~mm}$ thick and fixed in separation unit with 22 degree slope depending on the average coefficient friction of fiberglass. Shells discharge pan, it made of fiberglass, this pan consists of deflector cone, plastic net and surface discharge pan has slope depending on coefficient of friction with shells. The shells discharge pan was fixed on air column by using chloroform. Kernel outlet, kernel out let made from fiberglass, it has slope depending on coefficient of friction with kernel, it was fixed on air column using chloroform.

\section{Measurement instruments:}

1) Electric balance: Sartorius type, made in Japan, with accuracy of $0.0001 \mathrm{~g}$ was used for measuring weight of samples.

2) Electrical oven: with forced hot air circulation, VENTICELL55 type, and maximum temperature of $250^{\circ} \mathrm{c}$ to evaluate the moisture content.

3) An apparatus of friction angle measurement: The friction angle was measured by an instrument fabricated in the workshop of Agricultural Engineering Faculty, Al-Azhar University, various materials galvanized sheet and fiber glass were installed on the changeable plane to study the effect of these materials on the friction angle.

4) Anemometer: with Accuracy of $0.1 \mathrm{~m} / \mathrm{s}$, range measurement of 0 - 30 $\mathrm{m} / \mathrm{s}$. 
5) Feeding rate measurement apparatus: Feeding rate measurement apparatus consists of flat flexible belt has length of $2.05 \mathrm{~m}, 0.20 \mathrm{~m}$ width and $0.5 \mathrm{~mm}$ thickness to lade $1 \mathrm{~kg}$ mixture, belt was fixed in wooden frame by 4 bearing pulleys and was rotated by electric motor $(0.37 \mathrm{~kW}$, $1400 \mathrm{rpm}$ ), it was connected with a speed controller (inverter) of model No. SV004IC5-1, (Fig. 5).

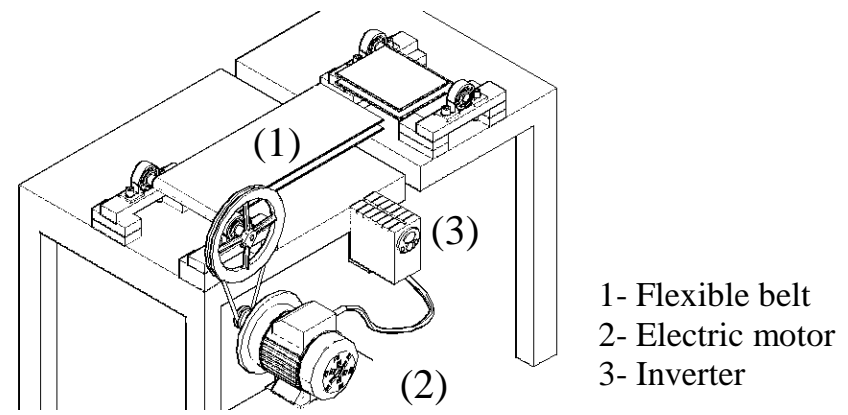

Fig. (5): Feeding rate measurement apparatus.

6) Terminal velocity apparatus: The apparatus (Fig. 4), (used by Awady and El- Sayed, 1994) was used to measure the terminal velocity for suspension of kernel and shells samples, it consists of a rectangular tube constructed from transparent (plexi-glass) and connected with the outlet of the electric blower, two wire screens were fitted at the bottom and top of the transparent tube, an air-flow straightener was attached with the lower screen to improve flow uniformity throw the rectangular tube, a choke valve is built as the inlet of blower to control the air flow rate manually by control lever.

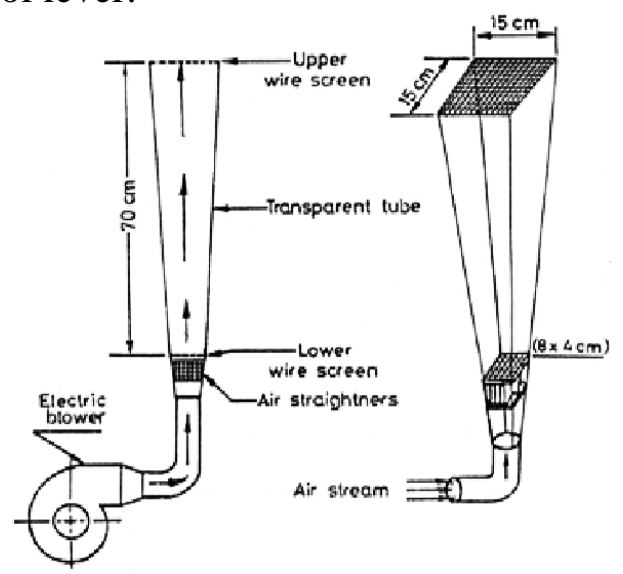

Fig. (4): Terminal velocity apparatus (Awady and El-sayed, 1994). 
PROCESS ENGINEERING

7) Digital AVO meter: with accuracy of device 0.01, range the measurement (0 - $40 \mathrm{~A})$.

8) Stop watch: with accuracy of $0.01 \mathrm{~s}$ to measure the separation time.

\section{Theoretical approach:}

According to physical proprieties of apricot kernel and shells can be definition the following:

4.1. Air stream velocity: suitable air stream velocity must be ranged between both of kernel terminal velocity and shells terminal velocity as following:

$$
V_{t(s h)}<V_{a}<V_{t(k)}
$$

4.2. Kernel motion on separation screen with slope: as shown in Fig.

$(6, a)$ to move kernel on screen must be:

$$
M_{k} g \sin \alpha \geq \mu M_{k} g \cos \alpha
$$

Also, kernel motion velocity $(\mathrm{Vm})$ can be calculated as following:

$$
V_{m}=\sqrt{2 g h \sin ^{2} \alpha+2 s\left(\frac{M_{k} g \sin \alpha-\mu M_{k} g \cos \alpha}{M_{k}}\right)}
$$

4.3. Shells motion that pushing with air force: as shown in Fig. $(6, \mathrm{~b})$

$$
\begin{gathered}
F_{a}=M_{s h} g+M_{s h} a \quad\left(\text { where } F_{a}>M_{s h} g\right) \\
1 / 2 C_{d} \rho_{a} A_{p} V_{a}^{2}=M_{s h} g+M_{s h} a_{(\text {acceleration })} \\
a_{\text {(acceleration) }}=\left(1 / 2 C_{d} \rho_{a} A_{p} V_{a}^{2}-M_{s h} g\right) / M_{s h}
\end{gathered}
$$

4.4. Height of air column (duct): as shown in Fig. $(6, b)$, the maximum rise for shell $(l)$ can be calculated as following - at this height, the velocity of shell $\left(V_{e}\right)$ is nihilistic -:

$$
\begin{gathered}
V_{\text {actual }}=V_{a}-V_{y} \\
V_{y}=V_{i} \sin \alpha \\
\therefore V_{\text {actual }}=V_{a}-\sin \alpha \sqrt{2 g h \sin ^{2} \alpha+2 s\left(\frac{M_{\text {sh }} g \sin \alpha-\mu M_{\text {sh }} g \cos \alpha}{M_{\text {sh }}}\right)} \\
\text { Also, } V_{e}^{2}=V_{\text {actual }}{ }^{2}-2 a l \\
\therefore l=\frac{V_{\text {actual }}}{2 a}
\end{gathered}
$$

This equation calculates the maximum of shell rise that pushed by air force, consequently, the high of air column (duct) must be less than value of the equation to let the shells out. 


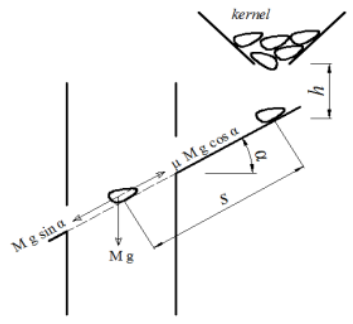

(a)

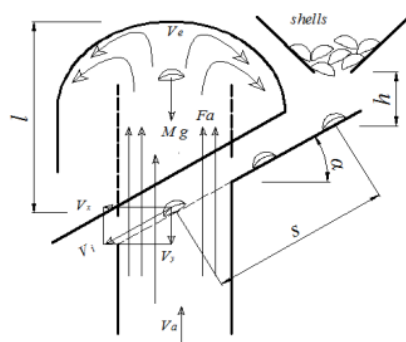

(b)

Fig. (6): Kernel and shells motions analysis.

\section{Physical properties:}

For study some physical properties for apricot kernel and shells, a random sample of 50 apricot pits were cracked mechanically (Tayel et al., 2011), 50 kernels and 304 pieces of shell were produced from cracking process. Some physical, mechanical and aerodynamic properties were evaluated in minimum mixture moisture contents of $5.76 \%$ w.b. ( $4.50 \%$ and $12.08 \%$ w.b. for shells and kernels, respectively). At this level of moisture content, the percent's of components in mixture were $69 \%$ and $31 \%$ for shells and kernel, respectively, properties were shown in Table (1).

Table (1): Properties of apricot pit kernel and its shells.

\begin{tabular}{|c|c|c|c|c|c|c|c|}
\hline \multirow{2}{*}{\multicolumn{3}{|c|}{ Properties }} & \multicolumn{2}{|c|}{ Range } & \multirow{2}{*}{ Mean } & \multirow{2}{*}{ S.D. } & \multirow{2}{*}{$\begin{array}{l}\text { C.V. } \\
(\%)\end{array}$} \\
\hline & & & Min. & Max. & & & \\
\hline \multirow{2}{*}{\multicolumn{2}{|c|}{ Mass $(M), \mathrm{g}$}} & Kernel $(k)$ & 0.32 & 0.61 & 0.47 & 0.07 & 14 \\
\hline & & Shells $(s h)$ & 0.02 & 0.62 & 0.19 & 0.11 & 57 \\
\hline \multirow{2}{*}{\multicolumn{2}{|c|}{ True Density $\left(\rho_{t}\right), \mathrm{kg} / \mathrm{m}^{3}$}} & Kernel & 913 & 1300 & 1100 & 82.9 & 8 \\
\hline & & shells & 625 & 1750 & 1286 & 247.2 & 19 \\
\hline \multirow{2}{*}{\multicolumn{2}{|c|}{ Projected area $\left(A_{p}\right), \mathrm{mm}^{2}$}} & Kernel & 102 & 158 & 124 & 12.94 & 10 \\
\hline & & shells & 25 & 193 & 91 & 34.95 & 39 \\
\hline \multirow{4}{*}{$\begin{array}{c}\text { Coefficient } \\
\text { of friction } \\
(\mu)\end{array}$} & \multirow{2}{*}{$\begin{array}{l}\text { Galvanized } \\
\text { iron }\end{array}$} & Kernel & 0.471 & 0.583 & 0.520 & 0.03 & 6 \\
\hline & & Shells & 0.456 & 0.577 & 0.526 & 0.03 & 6 \\
\hline & \multirow{2}{*}{ Fiberglass } & Kernel & 0.321 & 0.494 & 0.402 & 0.04 & 11 \\
\hline & & Shells & 0.372 & 0.515 & 0.426 & 0.04 & 8 \\
\hline \multirow{2}{*}{\multicolumn{2}{|c|}{$\begin{array}{c}\text { Terminal velocity }\left(V_{t}\right), \\
\mathrm{m} / \mathrm{s}\end{array}$}} & Kernel & 10.58 & 16.40 & 14.21 & 1.21 & 3 \\
\hline & & shells & 4.64 & 16.20 & 9.00 & 1.76 & 20 \\
\hline \multirow{2}{*}{\multicolumn{2}{|c|}{ Drag coefficient $\left(C_{d}\right)$. }} & Kernel & 0.24 & 0.41 & 0.29 & 0.03 & 12 \\
\hline & & shells & 0.10 & 1.25 & 0.38 & 0.08 & 21 \\
\hline
\end{tabular}

\section{Experimental procedure:}

The experiments were designed and carried out to study the effect of the following variables: $9,10,11$, and $12 \mathrm{~m} / \mathrm{s}$ air velocities; 30, 60, 90 and 
$120 \mathrm{~kg} / \mathrm{h}$ feeding rates; 5.76, 14.46 and $21.67 \pm 0.5 \%$ w.b. moisture contents; 25 and $35^{\circ}$ slopes of wire screen.

\section{Measurements:}

- Density: True volumes of the individual samples were determined using the liquid displacement method. Toluene $\left(\mathrm{C}_{7} \mathrm{H}_{8}\right)$ liquid was used because it's absorbed by samples to a lesser extent. Also, its surface tension is low (Mohsenin, 1970) and density was measured by divided true volume on mass of sample.

- Projected area: Projected area of kernels and shells samples was plotted to measure by using a scanner and the sample pictures were exported to Auto CAD 2007 program to calculate the area (Dosoky, 2011).

- The moisture content: Moisture content was determined using a digital electrical oven with forced hot air circulation. The moisture content for samples is evaluated according to ASAE standards (1994), by oven drying at $105^{\circ} \mathrm{c}$ for 24 hours. Moisture content was calculated on wet bases as follows:

$$
M . C .(\%)=\frac{M w-M d}{M w} \times 100
$$

Where:

Mw: Mass of wet samples, $\mathrm{kg}$; and

Md: Mass of dry samples, $\mathrm{kg}$.

The samples desired moisture content levels were achieved by incubated in water for 1 and 2 hours before the experiment (Inan, 2001), and samples were kept in fridge temperature for $48 \mathrm{~h}$ to complete absorption of humidity.

- Coefficient of Static Friction: Coefficient of static friction of a sample on two surfaces including galvanized iron and fiberglass were determined, a sample was put on the surface with adjustable slope. When a sample started to move, the tangent of the slope angle calculate as follows:

$$
\mu=\tan \theta=y / x
$$

Where, $\theta$ : Friction angle, degree. 
- Terminal velocity and drag coefficient: The terminal air velocity was measured using a terminal velocity apparatus according to Awady and El- sayed (1994). The sample was placed on the lower screen. Terminal velocity can be obtained by measuring the air velocity required to suspend the particles in the vertical air stream. Air velocity was measured at the bottom of the tube by an anemometer. The air velocity changes according to changes in the cross-section of the tube. The value of the terminal velocity $(V t)$ was calculated using the following expression:

$$
V t(m s-1)=\frac{\text { Air flow rate of subsiding the material, }\left(m^{3} s^{-1}\right)}{\text { cross section area of the tube, }\left(m^{2}\right)}
$$

When a particle is suspended into a turbulent stream of air, equilibrium is achieved between its weight $(M g)$ and the drag force, and can calculated drag coefficient as follows:

$$
C d=\left(\frac{2 M g}{V^{2} \times \rho a \times A p}\right)
$$

Where:

$C d$ : The coefficient of drag;

$\rho_{a}$ : air density, $\left(1.25 \mathrm{~kg} / \mathrm{m}^{3}\right)$;

$A_{p}$ : particle area projected to air stream, $\mathrm{m}^{2}$; and

$V_{t}$ : air terminal velocity, $\mathrm{m} / \mathrm{s}$.

\section{Parameters of technical evaluation:}

Parameters of technical evaluation were calculated as the following equations (Kashayap and Pandya, 1965):

$$
\begin{array}{ll}
K R .(\%)=\frac{K a}{K a+K b} \times 100 & K C .(\%)=\frac{K a}{K a+S H a} \times 100, \\
K C .(\%)=\frac{K a}{K a+S H a} \times 100 & \eta \cdot(\%)=K R \times S H R \times 100
\end{array}
$$

Where:

$K R$ : Kernel recovery;

$K C$ : kernel cleanliness;

$S H R$ : shells rejected;

$\eta$ : separation effectiveness; and
$K a$ : separated kernel, g;

$K b$ : kernel loss in shells outlet, g;

SHa: separated shells, g;

$S H b$ : shells outlet in separated kernel, g. 
- Productivity (Pr): Time of separating was measured by stopwatch to determine the kernel production using the following equation:

$$
\operatorname{Pr}=\frac{\text { Mass of separated kernel }(\mathrm{kg})}{\text { Time of separation }(h)}
$$

- Specific energy requirement (SER): The specific energy requirement was calculated using the following equation:

$$
S E R=\frac{\text { Power },(k W)}{\operatorname{Pr},(k g / h)}
$$

\section{- Cost analysis:}

The pneumatic separator economical and financial analyses were carried out calculation the following parameters, the methodology of estimating costs (L.E./h) was as follow (Hunt, 1983):

Total cost $($ L.E.h $)=$ Fixed $\operatorname{cost}($ L.E./h) + Variable cost $($ L.E./h $)$

A. Fixed costs:

1) Depreciation of machine $(D)$ : depreciation of machine (L.E./year) was calculated from the following equation:

$$
D=\frac{(P-S)}{L}
$$

Where:

$P$ : Purchase price, L.E. (350 L.E.);

$S$ : Selvage or Selling price, L.E. (Salvage $=10 \%$ of cost now); and

$L$ : Time between buying and selling, Year. (10 years).

2) Interest rate: interest rate was considered as a percentage of the machine purchase per year. (In Egypt, Interest rate was conceded 9\%).

3) Taxes, insurance and shelter: taxes, insurance and shelter were considered $2 \%$ of the machine purchase price per year.

B. Variable costs:

1) Repairs and maintenance: repairs and maintenance is about $5.77 \%$ of purchase price.

2) Electric cost $(K W)$ : Total power consumed was calculated according to (lockwood and dunstan, 1971) as following equation: 
PROCESS ENGINEERING

$$
K W=\frac{(I \cdot V \cdot u \cdot \cos \theta)}{1000}
$$

Where:

I: Current strength, amperes (Current strength was 1 ampere);

$V$ : Potential difference voltage (to $220 \mathrm{v}$ );

$\mu$ : Mechanical efficiency of motor (0.95); and

$\cos \theta$ : Power factor (being equal to 0.8 ).

Price $\mathrm{kW}$ of electric is 0.3 L.E. / kW.h.

3) Lubricant cost: lubricant cost was taken as (15\%) of electric cost.

4) Labor cost: labor wage was considered 900 L.E./month work so that the labor wage was 9000 L.E./year. Yearly working hours is assumed in the present work to be: (300 days/year $\times 8 \mathrm{~h} /$ day $=2400 \mathrm{~h} /$ year $)$.

C. Operating cost:

$$
\text { Cost of }(\text { L.E. } / \mathrm{kg})=\frac{\text { Unit hourly cost },(\text { L.E./h })}{\operatorname{Pr},(\mathrm{kg} / \mathrm{h})}
$$

\section{RESULTS AND DISCUSSIONS}

Effect of studied variables on separation effectiveness and percent of cleanliness:

The output of the apricot pits kernel and shell separation was classified as shown in Fig. (7)

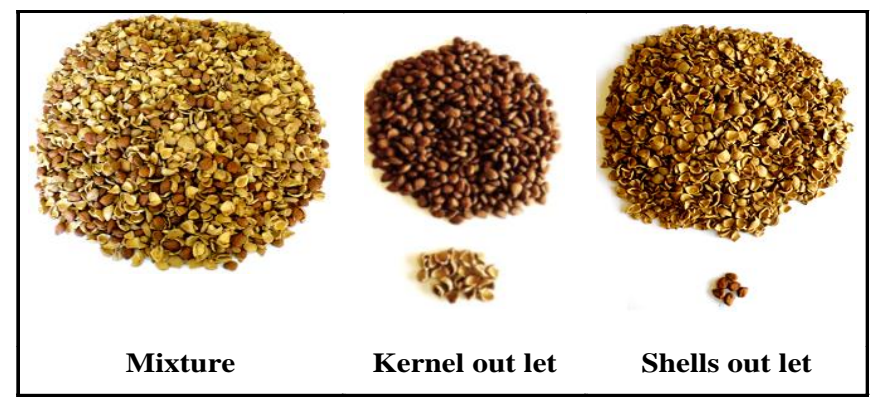

Fig. (7): Result of separation process.

\section{Effect of air velocity:}

Fig. (8) shows that the air stream velocity had a great effect on the performance of the separation unit, separation effectiveness was increased with increasing air velocity from 9 to $11 \mathrm{~m} / \mathrm{s}$, especially at upmost moisture content $(21.67 \%)$, while in case decreasing level 
moisture contents from (5.76 to $14.46 \%$ ), separation effectiveness decrease with increased of air velocity to $12 \mathrm{~m} / \mathrm{s}$ under all experimental conditions. The minimum mean effectiveness obtained was $45.53 \%$ when the air stream velocity, feeding rate, mixture moisture content and screen slope were $9 \mathrm{~m} / \mathrm{s}, 30 \mathrm{~kg} / \mathrm{h}, 21.67 \%$ and $35^{\circ}$ respectively. While the maximum value which was $96.18 \%$ when the air stream velocity, feeding rate, mixture moisture content and screen slope were $11 \mathrm{~m} / \mathrm{s}, 120 \mathrm{~kg} / \mathrm{h}$, $14.46 \%$ and $25^{\circ}$, respectively.

Fig. (9) shows the relationship between the air stream velocity and mean kernel cleanliness at different values of feeding rate, mixture moisture content and screen slope. The results showed that, by increasing air velocity from 9 to $12 \mathrm{~m} / \mathrm{s}$, kernel cleanliness increased under all experimental conditions .The minimum mean kernel cleanliness obtained was $49.82 \%$ when the air stream velocity, feeding rate, sample moisture content and screen slope were $9 \mathrm{~m} / \mathrm{s}, 30 \mathrm{~kg} / \mathrm{h}, 21.67 \%$ and $35^{\circ}$, respectively. While the maximum value which was $98.76 \%$ when the air stream velocity, feeding rate, sample moisture content and screen slope were $12 \mathrm{~m} / \mathrm{s}, 120 \mathrm{~kg} / \mathrm{h}, 5.76 \%$ and $25^{\circ}$, respectively.

This effect was due to the fact that, increase of air stream velocity gives the air stream opportunity to carry out most of shells because terminal velocity for shell less than kernel terminal velocity, while kernel losses increased more at air stream velocity of $12 \mathrm{~m} / \mathrm{s}$ especially at low levels of moisture content because the kernels were light, this leading to easy driftage kernel by air stream leading to reduced effectiveness in the end. These results are in agreement with Ismail et al. (1994) and Eissa (2009).

\section{Effect of moisture content:}

The results showed that, by increasing moisture content from 5.76 to $14.46 \%$ separation effectiveness and cleanliness increased slightly in all experimental treatments and then decreased at moisture content of $21.67 \%$. It was observed that, the increase of mixture moisture content from 5.76 to $21.67 \%$ caused decreased in percent of effectiveness, kernel cleanliness and kernel losses at all air stream velocities, feeding rates and screen slopes. This effect was due to the fact that, increase of mixture moisture content gives the mixture opportunity to resistance of air stream 
velocities. When moistening mixture to increase moisture content, notes that kernel absorption to water was higher than shells, that leads to decreased of kernel losses at moisture content of $14.46 \%$, while weight of shells un increased a lot at this moisture content, there explain the slightly increase in effectiveness and cleanliness at moisture content of $14.46 \%$. These results are in agreement with Ismail et al. (1994).

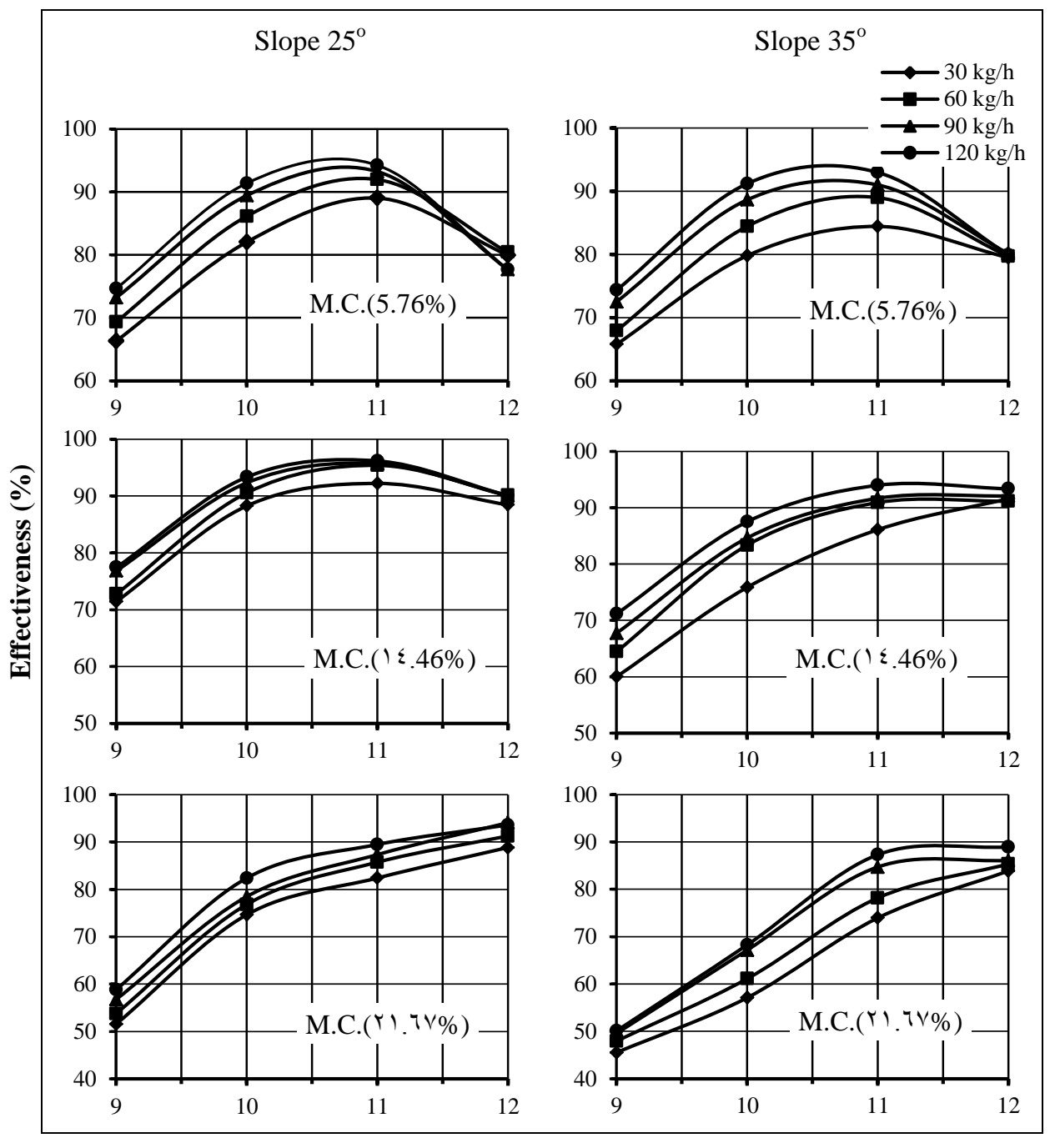

Air velocity (m/s)

Fig. (8): Effect of studied variables on separation effectiveness. 

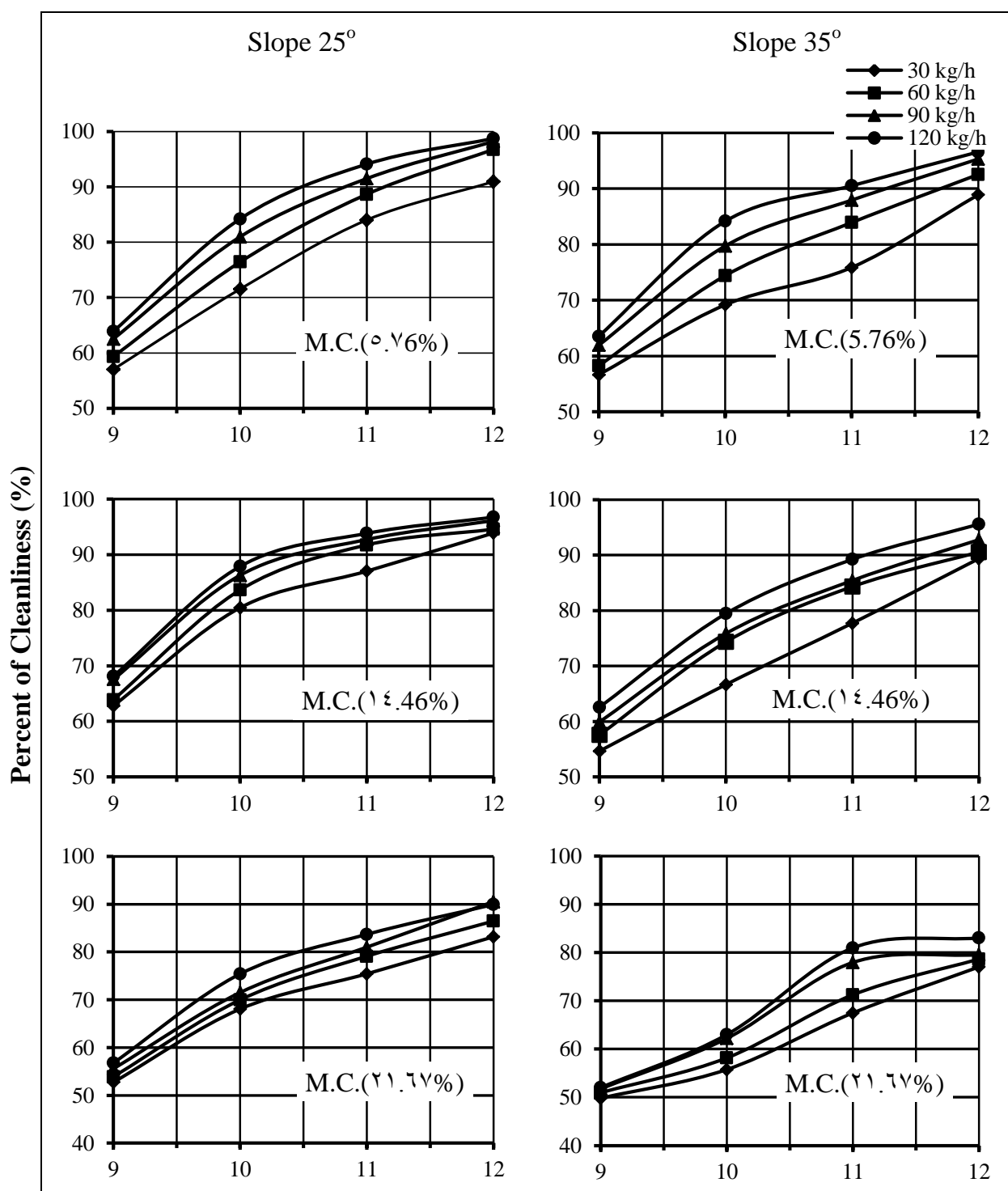

Air velocity $(\mathbf{m} / \mathbf{s})$

Fig. (9): Effect of studied variables on kernel cleanliness.

\section{Effect of feeding rate:}

The results showed that, by increasing feeding rate from 30 to $120 \mathrm{~kg} / \mathrm{h}$ separation effectiveness, kernel cleanliness and losses increased in all experimental treatments exclusive feeding rate of $120 \mathrm{~kg} / \mathrm{h}$ this was a little increase in separation effectiveness, this gave marked about outside for separation unit. These results are disagree old results. According to 
Ismael et al. (1994) and Eissa (2009); the effect of the specific feeding rate is related to the increase of the thickness of mixture layer throw the separation duct. Consequently, the separation condition got worse because that affects the air resistance per unit length. While, in this search this action not done because density for mixture are high. Also, design of feeding rate unit and its height from feed chute related to the decrease of the thickness of mixture layer and slowed moving throw the separation duct that not allow to overlap between layers of feeding.

\section{Effect of screen slope:}

Notes from figures that, increase of separation effectiveness, kernel cleanliness and losses at screen slope of $25^{\circ}$, while these factors of evaluations were less at screen slope of $35^{\circ}$. This result due to speed of bypassing of mixture through air column stream; while, this is not happen when used screen slope of $25^{\circ}$ because it is friction angle with material of screen.

\section{- Kernel productivity,}

Unit separation productivity was $40 \mathrm{~kg} / \mathrm{h}$.

\section{- Specific energy requirement:}

Specific energy requirement was $4.22 \mathrm{~kW} . \mathrm{h} / \mathrm{Mg}$.

\section{- Separation unit costs:}

Total separation unit costs were 3.85 L.E./h and 0.10 L.E./kg (96 L.E./Mg).

\section{CONCLUSION}

This research aimed to study the feasibility of separation of mixture of apricot kernel and shells. Some physical, mechanical and aerodynamic properties were studied for kernel and shells, and the type of separator (pneumatic separator) was selected according to different in terminal velocity between kernel and shells. The separation unit was performed by using a range of air stream velocities, mixture feeding rates, and screen slopes at different mixture moisture contents.

The optimum operating condition of separation was found at air stream velocity of $11 \mathrm{~m} / \mathrm{s}$, mixture feeding rate of $120 \mathrm{~kg} / \mathrm{h}$, screen slope of $25^{\circ}$ and average mixture moisture content of $14.46 \%$ where gave the best result of separation effectiveness of $96.18 \%$, kernel cleanliness of 
$93.15 \%$, kernel losses of $0.69 \%$, kernel productivity was $40 \mathrm{~kg} / \mathrm{h}$, specific energy requirement was $4.22 \mathrm{~kW} . \mathrm{h} / \mathrm{Mg}$ and cost was 0.10 L.E. $/ \mathrm{kg}$.

The research recommends feasibility of using pneumatic system to separate similar mixture products, such as shells and kernels of peach and plum pits, after studying the physical properties of these products.

\section{REFERENCES}

Agric. Statistics Economic Affairs Sector, (2011). Annual production handbook: 311-312.

Aksogan, S.; A. Basturk.; E. Yuksel and O. Akgiray, (2003). On the use of crushed shells of apricot as the upper layer in dual media filters. Water Science and Technology 48: 497-503.

ASAE, (1994). Standard Engineering practices data ISBN - 92935550. 4Lib. of Cong. By the ASAE: 529-532.

Awady, M. N. and A. S. El-sayed, (1994). Separation of peanuts seeds by air stream. Misr. J. Ag. Eng., 11(1):137-147.

Dorbrowksi, (2001). Adv. Colloid Interface Sci. 93-135.

Dosoky, S. H., (2011). Physical, mechanical and aerodynamic properties of soybeans for separation and grading machines. The 18th Annual Conference of the Misr Soc. of Agric. Eng., 26-27 October.

Eissa, A. H. A., (2009). Aerodynamic and solid flow properties for flaxseeds for pneumatic separation by using air stream. Int. jour. Agric. \& Boil. Eng. 2(4): 31-45.

Faronof, B. G and Baflofacke, (1959). Cleaning and storage seeds. National publication of Ag. Literature, Moscow.

Food and Agriculture Organization (FAO 2011). Statistics, FAO stat.

Gezer, I.; H. Haciseferogullari and F. Demir, (2002). Some physical properties of Hacıhaliloğlu apricot pit and its kernel. Journal of Food Engineering, 56: 49-57.

Hunt, D., (1983). Farm power and machinery management. $8^{\text {th }}$ Ed., low state Univ., Ames, USA.

Inan. A., (2001). On the feasibility of a novel apricot stone cracking machine, F.U. Fen ve Muh. Bilimleri Dergisi, 13, (2): 211-223.

Ismail, Z. E.; K. F. Hana and M. M. Kassem, (1994). Factors affecting grain cleaning efficiency, part 2: separating via vertical air streams. Msir J. Ag. Eng., 11(1): 227-238. 
Kashayap, M. M. and A. C. Pandya, (1965). A study of winnowing indices. J. Agric. Eng. Res., 10(3): 255 - 258.

Lock Wood, F. B. and R. Dunstan, (1971). Electrical engineering principles. Heinemann education books. Ltd. London.

Mohsenin, N.N., (1970). Physical properties of plant and animal materials. Gordon Breach Science Publishers, New York.

Ozcan, M., (2000). Composition of some apricot (Prunus armeniaca L.) kernels grown in Turkey. Acta Alimentaria, 29(3): 289-293.

Shah, G. H., (1985). Effect of processing factors on the quality of peach and apricot pulps and Physico-chemical changes during storage. $\mathrm{PhD}$ Thesis, Punjab Agriculture University, Ludhiana, India.

Tayel, S. A.; A. A. El-Nakib and A. K. Zaalouk, (2011). Some physical properties of Apricot pits. The 18th. Annual conference of the Misr Soc. of Ag. Eng., 26-27 October.

Vursavus, k. and Faruk, (2004). Mechanical behavior of apricot pit under compression loading. Journal of Food Engineering, 65: 255261.

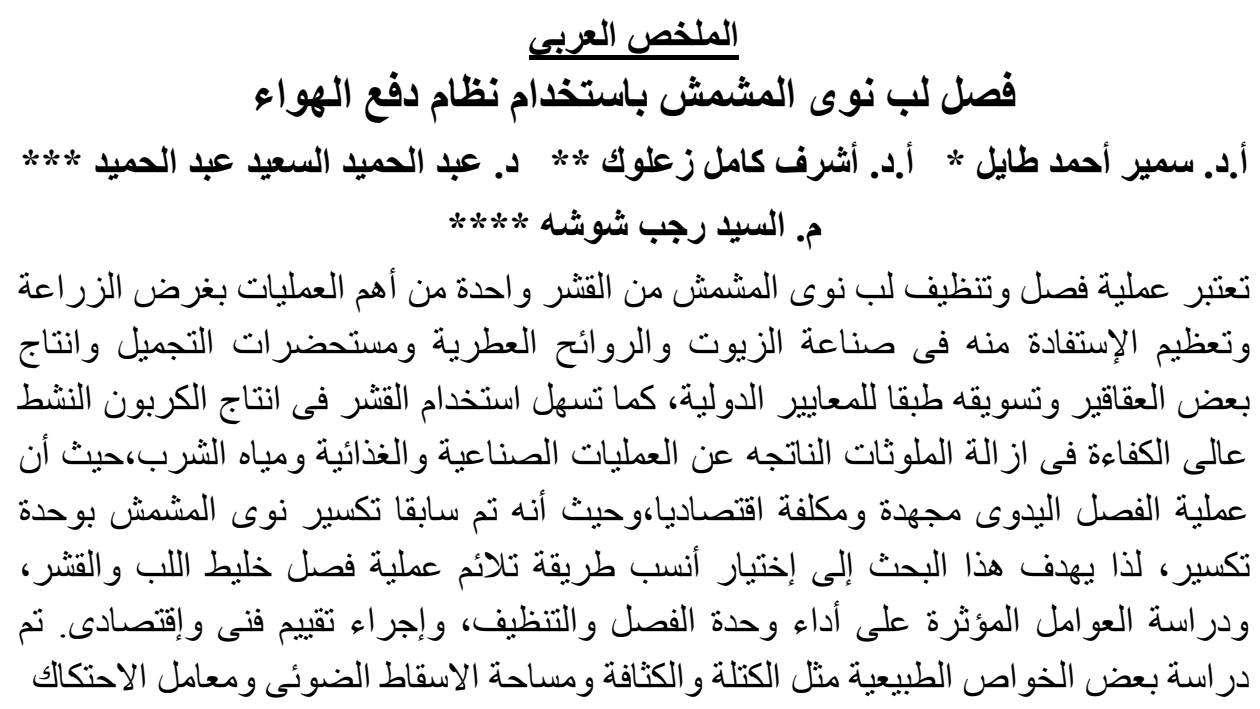

* أستاذ الهندسة الزراعية المتفرغ - كلية الهندسة الزراعية - جامعة الأزهر بالقاهرة.

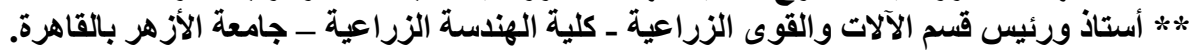

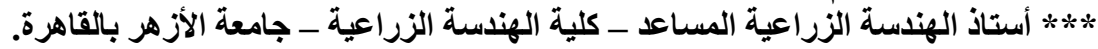
***** معيد بكلية الهناسة الزراعية - جامعة الأزهربالقاهرة. 
و السر عة الحرجة ومعامل الجرف لكل من لب وقتر نواة المشمش (صنف العمار) عند متوسط

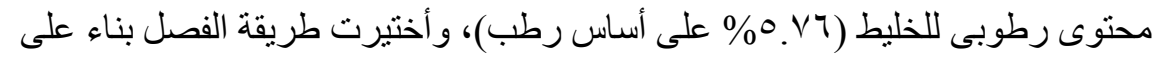

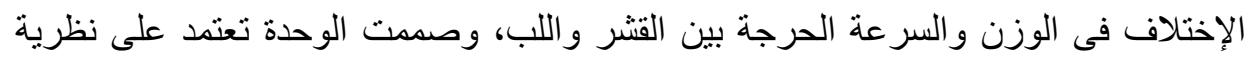

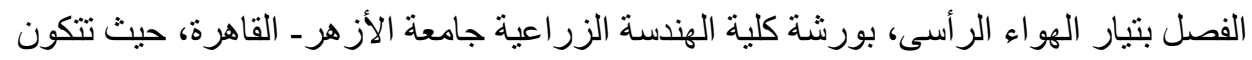
من سير للتغذية ووحدة الفصل، وتم إختبار الوحدة مع أربع سرعات لتيار الهواء ( 9 - . .

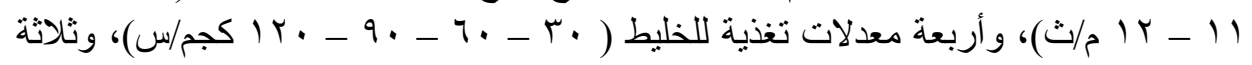

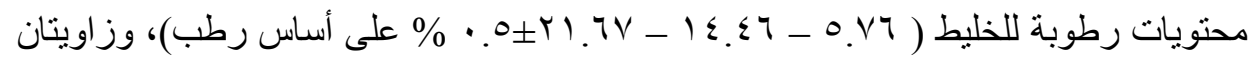

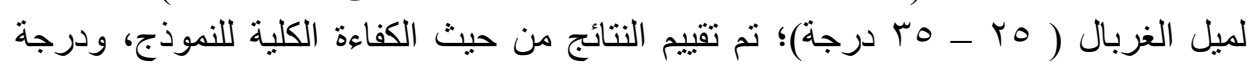

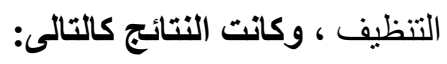
أولا: الخواص الطبيعية والميكانيكية والأيروديناميكية:

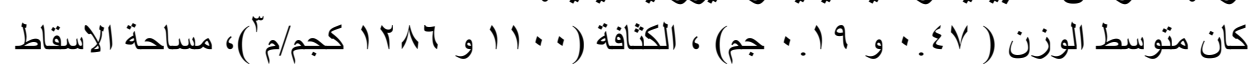

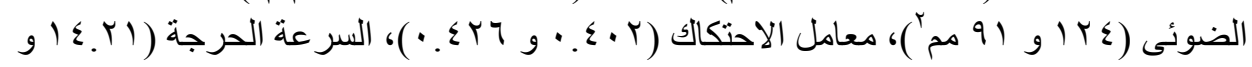

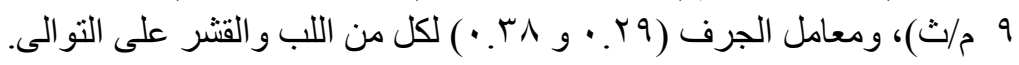

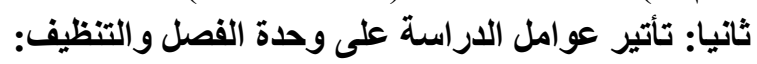

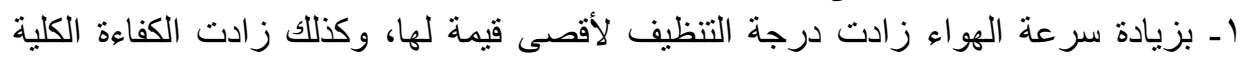
للوحدة حتى حد معين تم بدأت تثتاقص.

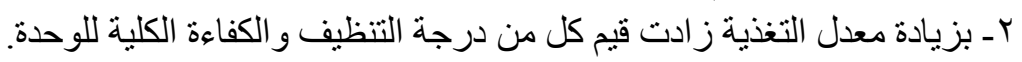
بـ بزيادة المحتوى الرطوبى زادت قيم كل من كفاءة الوحدة الكلية ودرجة التنظيف زيادة نسبية

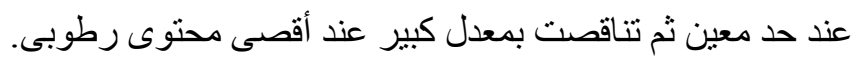
ع - بزيادة زاوية ميل الغربال قلت جميع قيم درجة التنظيف و الكفاءة الكلية للوحدة.

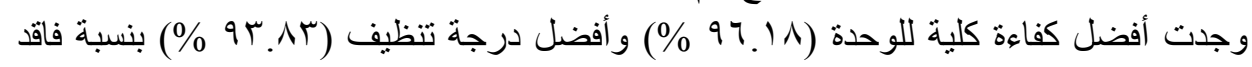

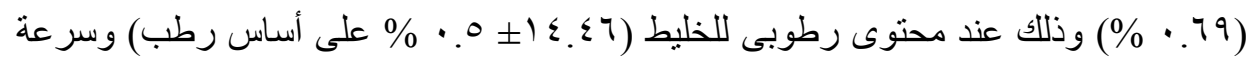

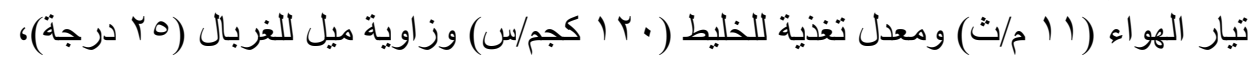

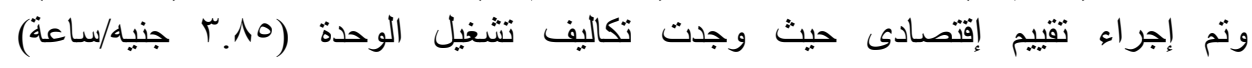

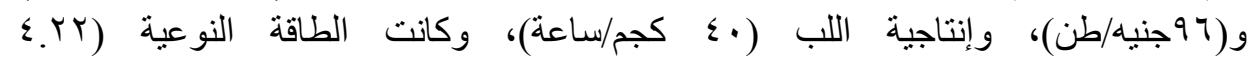

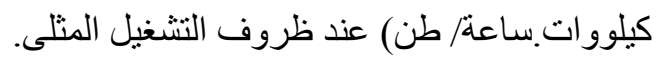

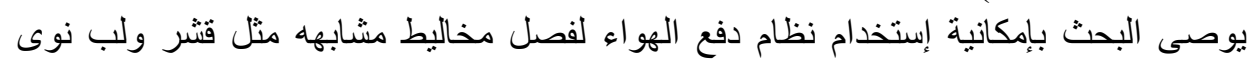
الخوخ و البرقوق وذلك بعد در اسة الخو اص الطبيعية لتلك المنتجات. 